\title{
In vitro assessment of plant growth-promoting potential of rhizosphere actinomycetes from Solanum tuberosum sp. andigena
}

\author{
Jessica Cisneros Moscol $\mathbb{D}^{\mathbb{D}}$; Junior Caro Castro ${ }^{\mathbb{D}}$; Claudia Mateo Tuesta ${ }^{\mathbb{D}}$; \\ Jorge León Quispe* (D)
}

Laboratorio de Ecología Microbiana, Facultad de Ciencias Biológicas, Universidad Nacional Mayor de San Marcos, Lima. Peru.

Received October 9, 2019. Accepted April 2, 2020.

\begin{abstract}
As part of the rhizosphere microbiota, actinomycetes interact with their host by releasing metabolites that positively influence their host' growth. The main objective of this study was to evaluate the plant growth-promoting capacity of actinomycetes isolated from the rhizosphere of potato crops collected in the city of San Jeronimo, Andahuaylas, Peru. Forty-nine actinomycetes strains were isolated and screened for their capacity to solubilize phosphates, fix atmospheric nitrogen, produce indole acetic acid (IAA) and produce siderophores. Out of the total number of isolates, $33(63.27 \%)$ solubilized phosphates, $42(87.72 \%)$ fixed atmospheric nitrogen, $10(20.41 \%)$ produced IAA and $18(24.49 \%)$ were siderophore producers; strains AND 13 and AND 16 being the top performers. AND 13 was identified by 16S RNAr gene amplification as Streptomyces sp. The results indicate that actinomycetes can be considered as potential PGPR organisms and could be included in biofertilization programs of potato crops as an alternative to agrochemicals.
\end{abstract}

Keywords: Rhizosphere; actinomycetes; native potato; biofertilizers; beneficial microorganisms.

\section{Introduction}

Solanum tuberosum "potato" is an ancestral crop originated in the Andes of Peru and Bolivia, whose domestication is attributed to ancient pre-Hispanic cultures that gradually adopted it as an important part of their diet (IDEXCAM, 2018).

The cultivation of this tuber presents several challenges that can impact its productivity and profitability. To control and mitigate these issues, farmers rely on the use of agrochemicals. However, the indiscriminate use of such toxic agents has led to a rapid increase in water, soil, and air pollution (FAO, 2008).

Plant growth-promoting rhizobacteria (PGPR) are considered beneficial microorganisms due to their positive influence on plant health, which has been reported in numerous investigations on different crops such as potatoes, beans, soybeans, citrus fruits, bananas, among others. PGPR bacteria positively interact with their host by producing phytohormones, solubilizing phosphates, fixing atmospheric nitrogen or controlling the action of pathogens. Frequently reported PGPR bacteria include strains from the genus Pseudomonas, Bacillus, Azospirillum, Azotobacter, Enterobacter and Serratia (Bhattacharyya and Jha, 2012; Sathya et al., 2017).

Actinomycetes, a heterogeneous group of soil microorganisms, are also considered part of these rhizobacterial group. Actinomycetes production of terpenoid compounds, pigments, organic matter-degrading enzymes, as well as several growth-promoting secondary metabolites has been documented (Franco, 2008). Moreover, they also can protect plants through biocontrol mechanisms against phytopathogens (Doumbou et al., 2001).

Cisneros Moscol, J.; Caro Castro, J.; Mateo Tuesta, C.; León Quispe, J. 2020. In vitro assessment of plant growth-promoting potential of rhizosphere actinomycetes from Solanum tuberosum sp. andigena. Scientia Agropecuaria 11(3): $391-398$. 
In recent years, the interest in using rhizosphere actinomycetes as plant promoting microorganisms has increased because of documented production of important metabolites of agricultural interest (Anwar et al., 2016). The bioprospection of PGPR surges as a biological strategy to improve soil fertility and crop yield, and to reduce the negative effect of chemical fertilizers on the environment (Franco and Chavarro, 2016). Actinomycetes constitute a significant percentage of the soil microbial community. The genus Streptomyces, one of the most abundant and biotechnology-promising group of actinomycetes, is a source of numerous bioactive compounds, antibiotics and extracellular enzymes. Members of this genus have shown great potential to improve the future of sustainable agriculture due to their biocontrol and biofertilizer activities (Olanrewaju and Babalola, 2019).

Several evaluations that reported the plant growth-promoting capacity of rhizosphere actinomycetes can be found on the literature. Some studies focused on screening for rhizosphere actinomycetes from wheat and tomato to obtain agroactive compounds (Anwar et al., 2016); isolating and characterizing actinomycetes from vermicompost and rhizosphere soil for plant growth-promotion in chickpea (Sreevidya et al., 2016); isolating and evaluating the growth promoting effects of antagonistic actinomycetes strains from Mikania micrantha (Han et al., 2018); assessing indol-3-acetic acid production of actinomycetes isolated from soybean rhizosphere (Wahyudi et al., 2019); and biocontrolling root disease of Aconitum carmichaelii induced by Streptomyces pactum and Streptomyces rochei ( $\mathrm{Li}$ et al., 2019).

The objective of this study was to isolate and identify PGPR actinomycete strains from Solanum tuberosum sp. andigena cultivated in the city of Andahuaylas, Apurímac, which could become a useful alternative in the production chain of this tuber.

\section{Materials and methods Sampling of rhizosphere soil}

Solanum tuberosum sp. andigena rhizosphere samples were collected from the city of Andahuaylas, Apurímac, Peru; between the months of January and April 2014. Sampling areas were specifically located in the

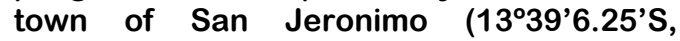
$\left.7^{\circ} 21^{\prime} 35.24^{\prime} O\right)$. Two random potato plants were taken from each sampling site, obtaining $200 \mathrm{~g}$ of rhizosphere soil (Calvo, 2008). These were placed in sterile polyethylene bags with airtight closure and transported to the laboratory in aseptic conditions.

\section{Isolation of actinomycetes}

Soil samples were dried in an oven (Memmert UNB300) at $50^{\circ} \mathrm{C}$ for 1 hour. Ten grams of dried sample were dissolved in 90 $\mathrm{mL}$ of $0.85 \%$ Saline Solution (SS) with $1.5 \%$ of phenol and incubated immediately after for 30 minutes at $30{ }^{\circ} \mathrm{C}$ (Memmert BE400). Dilutions were prepared in SS up to 10-4 and $0.1 \mathrm{~mL}$ of each dilution was inoculated into Casein Starch Agar plates pH 7.2 supplemented with Nystatin (Merck) (50 $\mu \mathrm{g} / \mathrm{mL}$ ) and Cycloheximide (Merck) (50 $\mu \mathrm{g} / \mathrm{mL}$ ). Plates were incubated at $28^{\circ} \mathrm{C}$ for 15 days.

\section{Phosphate solubilization}

The phosphate solubilization test was performed as described in Vásquez et al. (2000). The strains were reactivated in Tryptic Soy Broth (TSB) and incubated for 5 days at $28{ }^{\circ} \mathrm{C}$ until reaching a concentration of 108 spores $/ \mathrm{mL}$. Fifteen microliters of each strain were inoculated in Picovskaya medium supplemented with tricalcium phosphate and incubated at $30^{\circ} \mathrm{C}$ for 20 days. The formation of a transparent halo around the colonies was indicative of phosphate solubilization in the medium. Likewise, the strains were cultured in SRSM-1 medium (Gunmarsson et al., 2004) to evaluate the production of organic acids, measured by the variation in $\mathrm{pH}$ of the medium caused by phosphate solubilization. The halo area was calculated to measure of each strain capacity to solubilize phosphates (circular crown formula: $A=\pi(R 2-r 2)$, where $R$ : radius of the solubilization halo and $r$ : radius of the bacterial colony).

\section{Nitrogen fixation}

Actinomycete colonies were streaked into nitrogen-free agar (NFA) and incubated at $30{ }^{\circ} \mathrm{C}$ for 15 days, as described in Valdés et al. (2005). The nitrogen fixation capacity was measured by determining the strain growth at the expense of atmospheric nitrogen.

Indole acetic acid (IAA) production

IAA production was determined by the method of Celis and Gallardo (2008). The strains were inoculated in Broth B supplemented with tryptone and incubated at $22{ }^{\circ} \mathrm{C}$ with $125 \mathrm{rpm}$ agitation for 15 days. After this time, $5 \mathrm{ml}$ of the culture were centrifuged at $3000 \mathrm{rpm}$ for 15 minutes, and $100 \mu \mathrm{l}$ of the supernatant were transferred into microplate wells. The supernatants were mixed with $200 \mu \mathrm{L}$ of Salkowsky reagent and incubated in dark for 15 minutes. IAA production was determined qualitatively by the appearance of yellow color and different shades of fuchsia in the medium. The quantitative determination was performed by using a spectrophotometer 
(Unico UV2102C) at $530 \mathrm{~nm}$ absorbance of the positive strains.

\section{Siderophores production}

The actinomycetes were inoculated in the medium described by Simon and Tessman (1963) and incubated at $22{ }^{\circ} \mathrm{C}$ with $250 \mathrm{rpm}$ agitation for 15 days. The qualitative test was determined by the appearance of a red-coffee color after the supernatant is mixed with ferric perchlorate (Sigma-Aldrich) in perchloric acid. The quantitative evaluation was determined as suggested by Atkin (1970) by using a spectrophotometer at $580 \mathrm{~nm}$ absorbance (Unico UV2102C). In all cases, the PGPR tests were carried out in duplicates and using strains of Azotobacter sp. and Pseudomonas sp. as positive controls.

Molecular identification of actinomycetes

16S rRNA gene amplification was performed by PCR as reported by Cook and Meyer (2003), using extracted actinomycete genomic DNA as a template. The primers used were $27 \mathrm{~F}\left(5^{\circ}-\right.$ AGAGTTTGATCMTGGCTCAG-3') and 1492R (5'-GYTACCTTGTTACGACTT-3'). The PCR products were sent to Macrogen (Korea) for sequencing analysis, and the result was evaluated as part of a construction of a phylogenetic tree using MEGA7 software. Sequences of actinomycetes downloaded from the National Center of Biotechnology Information (NCBI) were included, as well as Bacillus subtillis sequences to be utilized as external group. Phylogenetic analysis was performed using the Neighbor Joining method with 1000 of boostrap.

\section{Results and discussion}

Characterization of actinomycetes isolates and its importance as PGPR organisms

A total of 49 strains of rhizosphere actinomycetes were isolated. Isolation was based on macroscopic examination and Gram staining. Gram staining allowed confirmation of Grampositive filamentous bacteria. Macroscopic morphology suggested that the isolates belong to the genus Streptomyces. Detailed macroscopic characteristics are shown in Table 1.

Reports of actinomycetes associated to the rhizosphere of potato with PGPR potential are limited. Our results showed similarities in terms of the number and the morphological characteristics found by Rico (2009), who isolated and characterized 45 actinomycetes strains from potato crops collected from 4 different regions in Peru. Another study authored by Oswald and Calvo (2009), reported 82 actinomycetes strains associated with potatoes from the Central Andes of Peru. The work of Camacho and La Torre (2015) reported the finding of actinomycetes associated with potato crops in different substrates and controlled systems.

Table 1

Macroscopic characteristics of actinomycetes isolated from the rhizosphere of Solanum tuberosum $(n=49)$

\begin{tabular}{|c|c|c|c|}
\hline \multirow[b]{2}{*}{ Strain } & \multicolumn{3}{|c|}{$\begin{array}{l}\text { Macroscopic characteristics of the } \\
\text { colonies }\end{array}$} \\
\hline & $\begin{array}{c}\text { Aerial } \\
\text { mycelium }\end{array}$ & $\begin{array}{c}\text { Aerial } \\
\text { mycelium }\end{array}$ & $\begin{array}{c}\text { Colony reverse } \\
\text { color }\end{array}$ \\
\hline AND 1 & + & Cream & Light brown \\
\hline AND 2 & + & Cream & Pink \\
\hline AND 3 & + & Green & Beige \\
\hline AND 4 & + & Beige & Light brown \\
\hline AND 5 & + & Cream & Light brown \\
\hline AND 6 & + & Cream & Light brown \\
\hline AND 7 & + & Grey white & Grey \\
\hline AND 8 & + & White & Light green \\
\hline AND 9 & + & White & Light green \\
\hline AND 10 & + & Purple & Purple \\
\hline AND 11 & + & Brown & Dark brown \\
\hline AND 12 & + & Grey white & Grey \\
\hline AND 13 & + & White & Cream \\
\hline AND 14 & + & White & Yellow \\
\hline AND 15 & + & White & Light yellow \\
\hline AND 16 & + & White & White \\
\hline AND 18 & + & White & Pink \\
\hline AND 19 & + & White & Beige \\
\hline AND 20 & + & White & Cream \\
\hline AND 21 & + & Cream & Pink \\
\hline AND 22 & + & White & Pink \\
\hline AND 23 & + & White & Pink \\
\hline AND 24 & + & White & Pink \\
\hline AND 25 & + & White & Cream \\
\hline AND 26 & + & White & Cream \\
\hline AND 27 & + & White & Cream \\
\hline AND 28 & + & White & Cream \\
\hline AND 29 & + & Cream & Beige \\
\hline AND 30 & + & Light brown & Grey \\
\hline AND 31 & + & White & Cream \\
\hline AND 32 & + & White & Cream \\
\hline AND 33 & + & White & Cream \\
\hline APW 1 & + & Grey white & Light brown \\
\hline APW 2 & + & White & Light brown \\
\hline APW 3 & + & Cream & Light brown \\
\hline APW 4 & + & White & Light brown \\
\hline APW 5 & + & White & Dark brown \\
\hline APW 6 & + & White & Dark brown \\
\hline APW 7 & + & White & Dark brown \\
\hline APW 8 & + & White & Light brown \\
\hline APW 9 & + & White & Dark brown \\
\hline APW 10 & + & Beige & Light brown \\
\hline APW 11 & + & White & Cream \\
\hline APW 13 & + & White & Light yellow \\
\hline APW 15 & + & White & Cream \\
\hline APW 16 & + & White & Cream \\
\hline APW 17 & + & White & Dark brown \\
\hline APW46b & + & White & Cream \\
\hline APW $49 \mathrm{~g}$ & + & White & Cream \\
\hline
\end{tabular}

\section{In vitro evaluation of actinomycetes as} PGPR

\section{Phosphate solubilization}

The first evidence of phosphate solubilization was observed in SRSM-1 medium, in which 38 actinomycetes strains (77.55\%) showed acidification. This activity was later confirmed in 33 isolates $(63.27 \%)$ which grew in Picovskaya medium (Figure 1), showing solubilization areas also called "halos". Solubilization areas ranged from 0.02 to $0.06 \mathrm{~cm}^{2}$ (Table 2), AND 27 being the strain with the largest halo area. 


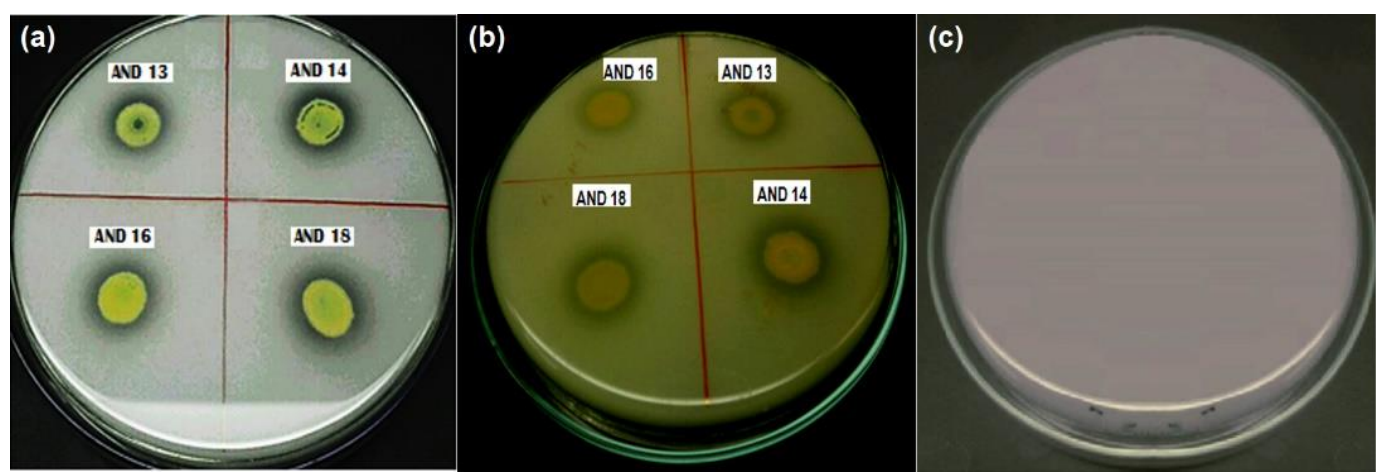

Figure 1. Phosphate solubilization test in (a) Picovskaya Agar and (b) SRSM-1 Agar (with acidification of the medium); (c) Control without inoculation.

Many microorganisms are capable of dissolving inorganic phosphate to make it available to plants to increase crop yield (Rodríguez et al., 2006; Jog et al., 2014). In the present study, more than $60 \%$ of the strains presented halos of solubilization; however, these halos were very small compared to those seen in the standard strain Azotobacter sp. (approximately1 $\mathrm{cm}^{2}$ ). Franco (2008) obtained similar results, where a large amount of phosphate-solubilizing actinomycetes yielded poorly compared to Azotobacter. These results suggest that not all microorganisms have the same capacity to solubilize phosphorus from inorganic sources. Moreover, Rico (2009) found that only $11 \%$ of the rhizosphere actinomycetes isolated from potatoes showed phosphate solubilization halos ranging from 0.13 to $0.35 \mathrm{~cm}^{2}$. These results differ from ours in terms of percentage of positive cases and halo size.

\section{Nitrogen fixation}

42 actinomycetes strains $(87.72 \%)$ grew in the NFA media, inferring that growth was possible because of the strain ability to grow at the expense of fixed atmospheric nitrogen. In general, growth was restricted; somewhat between scarce and regular (Table 2). The first colonies appeared in the medium after 5 days of incubation.

Nitrogen is an essential element for plant development, especially for the formation of their molecular structures. Natural nitrogen fixation occurs mainly in the rhizosphere area and is strictly performed by microbial organisms, symbiotic or asymbiotic, thanks to the activity of their own nitrogenase complex (Zahir, 2004).

The first report of nitrogen-fixing actinomycetes refers to a strain of Streptomyces thermoautotrophicu not associated with plants (Valdés et al., 2005). In our study, more than $85 \%$ of the rhizosphere actinomycetes strains were found to have the capacity to fix nitrogen. This rate is much higher than those reported by Franco (2008) and Salazar and Ordóñez (2013), where the capacity to fix nitrogen in the isolated actinomycetes were $33.3 \%$ and $68 \%$, respectively.

\section{Production of indole acetic acid (IAA)}

The colorimetric method used to determine IAA production led to the identification of 10 positive strains of actinomycetes $(20.41 \%)$. However, it was observed that the supernatants showed a slight red color, evidencing the low production of IAA compared to the positive control (Pseudomonas sp.) (Figure $2 \mathrm{a}$ and $2 \mathrm{~b}$ ). Moreover, the quantification of IAA was only possible using a calibration curve $\left(y=0.021 x+0.0364 ; r^{2}=0.994\right)$ obtained through a linear regression. This equation was used as a reference standard for the quantitative calculation of IAA concentrations produced by the evaluated strains.

Results from the IAA tests ranged from 3.9 $\mu \mathrm{g} / \mathrm{mL}-9.9 \mu \mathrm{g} / \mathrm{mL}$ and are shown in Table 2 . AND 10 produced the highest concentration of IAA $(9.9 \mu \mathrm{g} / \mathrm{mL})$ followed by AND 13 (5.5 $\mu \mathrm{g} / \mathrm{mL}$ ).

PGPR activity includes the production of phytohormones or plant growth regulators, being auxins such as IAA the most important (Ahmad et al., 2008). Auxins are a group of compounds that stimulate elongation of stems and roots. They can induce differentiation of vascular filaments of plants in which the flow of auxins is essential to initiate the formation of vascular tissues.

At the end of the evaluation, only $20.41 \%$ of positive strains were obtained. These results are not very encouraging; however, it should be considered that the evaluation was carried out at the end of the day 15 , without a continuous evaluation in the previous days. The work conducted by Rico (2009) evaluated the production of IAA in rhizosphere strains of potato on days $4,8,12$ and 15 , obtaining a variation between $6.9 \mu \mathrm{g} / \mathrm{ml}$ and $51.8 \mu \mathrm{g} / \mathrm{ml}$ on day 15 . Studies with rhizosphere strains other than potato and in other 
latitudes, performed by Franco (2008) found that actinomycetes produced an IAA maximum value of $11.9 \mu \mathrm{g} / \mathrm{mL}$. These values are low compared to the evaluation made by Matsukawa et al. (2007) who found IAAproducing actinomycetes strains that reached a concentration of $51.5 \mu \mathrm{g} / \mathrm{ml}$. Despite the low values obtained here, a low concentration of IAA can stimulate plant growth, while high concentrations inhibit or reduce the elongation zone (Hernández, 2002). Considering that native microorganisms are adapted to their own environments and conditions; the execution of in vivo bioassays could help us find the appropriate dose and determine the actual effect on crops.

\section{Siderophores production}

The qualitative detection of siderophores performed by a colorimetric test led to the detection of 18 siderophore-producing strains (24.49\%) (Figure 2c). Quantitative analysis of siderophore production was done by linear regression of a standard curve using Desferal (siderophore of desferrioxamine type). Siderophore concentrations in all strains were calculated from the equation $\left(y=0.0024 x+0.0115 ; r^{2}=0.9982\right)$ as shown in Table 2. The most representative actinomycetes were AND 13 and AND 16 with siderophore concentrations of 1.7 $\mu \mathrm{g} / \mathrm{mL}$ and $0.8 \mu \mathrm{g} / \mathrm{mL}$, respectively. The range of siderophore concentration among all strains went from $0.07 \mu \mathrm{g} / \mathrm{mL}$ to 1.88 $\mu \mathrm{g} / \mathrm{mL}$.

A frequent challenge for plants nutrition is the low availability of assimilable iron in soils, which occurs because of its precipitation into insoluble forms. Siderophores that are produced by several microorganisms have high affinity for iron. Microbial siderophores can increase or regulate the availability of iron in the rhizosphere and can also protect plants from the attacks of certain pathogens (Crowley, 2006). Numerous strains of actinobacteria have been reported as producers of catechol-type and hydroxamate siderophores, Streptomyces being widely known for its siderophores of high affinity (Wang et al., 2014).

Table 2

PGPR activities of rhizosphere actinomycetes of $S$. tuberosum $(n=49)$

\begin{tabular}{|c|c|c|c|c|}
\hline \multirow[b]{2}{*}{$\begin{array}{l}\text { Strain } \\
\text { name }\end{array}$} & \multicolumn{4}{|c|}{ PGPR activities } \\
\hline & $\begin{array}{l}\text { Phosphate } \\
\text { solubilization } \\
\text { area }\left(\mathrm{cm}^{2}\right)\end{array}$ & $\begin{array}{l}\text { Nitrogen } \\
\text { fixation }\end{array}$ & $\begin{array}{c}\text { AA concen } \\
\text { tration } \\
(\mu \mathrm{g} / \mathrm{mL})\end{array}$ & $\begin{array}{c}\text { Sidero- } \\
\text { phores } \\
\text { concen- } \\
\text { tration } \\
(\mu \mathrm{g} / \mathrm{mL})\end{array}$ \\
\hline AND 1 & - & + & 0 & 0 \\
\hline AND 2 & - & + & 0 & 0 \\
\hline AND 3 & - & - & 0 & 0 \\
\hline AND 4 & - & + & 0 & 0.07 \\
\hline AND 5 & - & + & 4.4 & 0 \\
\hline AND 6 & - & + & 5.2 & 0 \\
\hline AND 7 & - & + & 0 & 0.21 \\
\hline AND 8 & - & + & 0 & 0 \\
\hline AND 9 & - & - & 0 & 0 \\
\hline AND 10 & 0.05 & - & 9.9 & 0 \\
\hline AND 11 & - & + & 0 & 0.21 \\
\hline AND 12 & - & + & 4.5 & 0 \\
\hline AND 13 & 0.04 & + & 5.5 & 1.72 \\
\hline AND 14 & 0.05 & + & 0 & 0 \\
\hline AND 15 & - & + & 0 & 0 \\
\hline AND 16 & 0.03 & + & 5.3 & 0.8 \\
\hline AND 18 & - & + & 0 & 0 \\
\hline AND 19 & - & + & 0 & 0 \\
\hline AND 20 & - & + & 0 & 0 \\
\hline AND 21 & - & + & 0 & 0.49 \\
\hline AND 22 & 0.03 & + & 4.5 & 0 \\
\hline AND 23 & 0.04 & - & 0 & 0 \\
\hline AND 24 & 0.05 & + & 0 & 0 \\
\hline AND 25 & 0.03 & + & 0 & 0 \\
\hline AND 26 & 0.03 & + & 0 & 0.07 \\
\hline AND 27 & 0.06 & + & 0 & 0 \\
\hline AND 28 & 0.04 & + & 3.9 & 0 \\
\hline AND 29 & 0.03 & + & 0 & 0 \\
\hline AND 30 & 0.04 & + & 0 & 0 \\
\hline AND 31 & 0.03 & + & 0 & 0 \\
\hline AND 32 & 0.05 & - & 4.1 & 0.21 \\
\hline AND 33 & 0.04 & + & 0 & 0.07 \\
\hline APW 1 & 0.03 & + & 0 & 0 \\
\hline APW 2 & 0.04 & + & 0 & 0 \\
\hline APW 3 & 0.05 & + & 0 & 0.49 \\
\hline APW 4 & 0.03 & + & 0 & 0 \\
\hline APW 5 & 0.04 & + & 0 & 0 \\
\hline APW 6 & 0.03 & - & 0 & 0 \\
\hline APW 7 & - & - & 0 & 0.07 \\
\hline APW 8 & - & + & 0 & 0.07 \\
\hline APW 9 & 0.04 & + & 0 & 0 \\
\hline APW 10 & 0.04 & + & 0 & 0 \\
\hline APW 11 & 0.05 & + & 0 & 0 \\
\hline APW 13 & 0.03 & + & 0 & 0 \\
\hline APW 15 & 0.04 & + & 0 & 0 \\
\hline APW 16 & 0.04 & + & 4.3 & 0 \\
\hline APW 17 & 0.02 & + & 0 & 0 \\
\hline APW46b & 0.03 & + & 0 & 0 \\
\hline APW49g & 0.04 & - & 0 & 0 \\
\hline
\end{tabular}

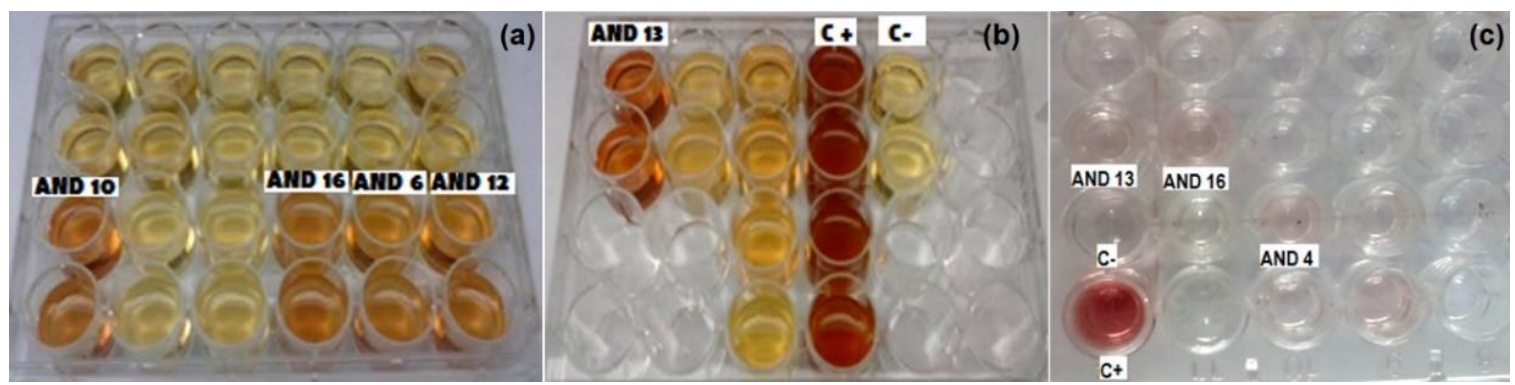

Figure 2. Colorimetric test for the detection of IAA (A and B) and siderophores (C) produced by some strains of actinomycetes from the rhizosphere of $S$. tuberosum. C +: positive control, C-: negative control. 


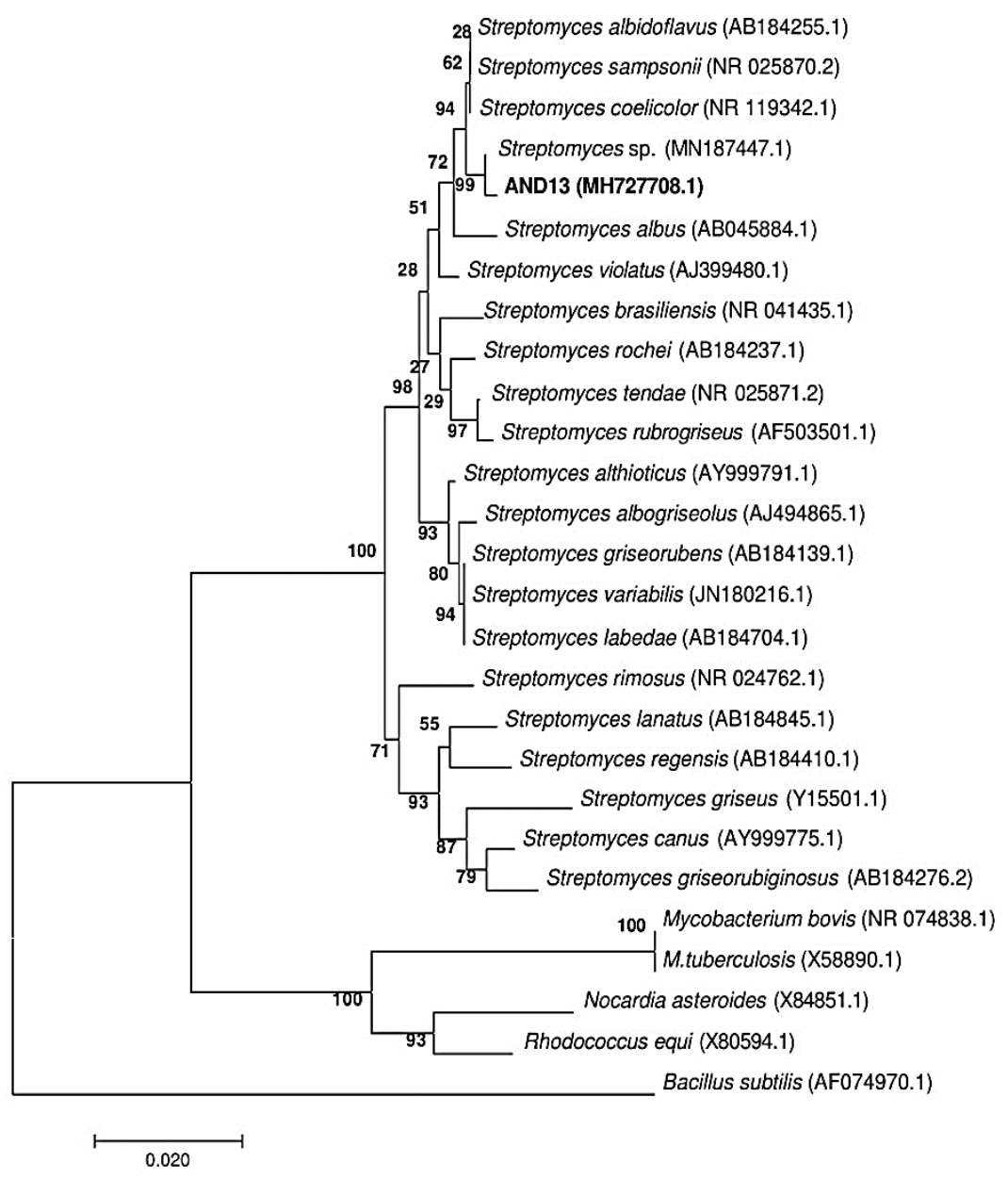

Figure 3. Phylogenetic tree of actinomycete AND 13 based on the sequence of the 16S rRNA built with Mega version 6 , using Neighbor-Joining statistical method with 1000 of bootstrap, identifying the strain as Streptomyces sp. with $99 \%$ of similarity percentage.

Although $24.49 \%$ of all evaluated strains were positive, the concentration of siderophore detected was minimal. Franco (2008), who used the same medium, also obtained positive strains but with low concentrations of this metabolite. Medium might influence the production or concentration of siderophores. For example, Rico (2009) obtained negative results for all tested strains, high lighting a different culture medium was used in the study.

\section{Molecular identification of actinomycetes} strain AND 13

Preliminary analysis of AND 13 indicated that it was a member of the genus Streptomyces, this was also confirmed by phylogenetic analysis. A sequence of 1292 base pairs (bp) from 16S rRNA gene was obtained by sequencing. The sequence was compared to GenBank database, obtaining $99 \%$ of similarity with another collection strain identified as Streptomyces sp. (Figure $3)$. The rRNA 16S gene sequence was deposited in GenBank database with the access code $\mathrm{MH} 727708.1$.

Streptomyces sp. is well known because of its wide distribution in nature, especially in the soil, and because of its antibioticproducing capacity (Franco and Chavarro, 2016).

\section{Conclusions}

Actinomycetes isolated from $S$. tuberosum sp. andigena rhizosphere are promising candidates to be used as plant growthpromoting rhizobacteria. Even though the results from this study are qualitatively or quantitatively inferior to other studies, it is evident that rhizosphere actinomycetes are an attractive option for the formulation of agro-active compounds for potato crops, helping to increase and develop sustainable production of this tuber under diverse conditions. Moreover, it lays the groundwork for continuing research focused on actinomycetes, a bacterial group that has not been 
used yet as a bioinoculant to improve the production of essential crops.

\section{Acknowledgements \\ The authors thank Vicerrectorado de Investiga- ción y Postgrado (VRIP) - Universidad Nacional Mayor de San Marcos for the provided funding under the Undergraduate Thesis Promotion Fund (Project Code: 151001057) (RR No. 00741-R-15). \\ ORCID \\ J. Cisneros $\mathbb{D}$ https://orcid.org/0000-0002-2494-7173 \\ J. Caro $\mathbb{D}$ https://orcid.org/0000-0002-8890-6119 \\ C. Mateo $\mathbb{D}$ https://orcid.org/0000-0002-3028-7300 \\ J. León (D) https://orcid.org/0000-0001-5865-5374}

\section{References}

Ahmad, F.; Ahmad, A.I.; Khan, M.S. 2008. Screening of free-living rhizospheric bacteria for their multiple plant growth promoting activities. Microbiol. Res. 163: 173-181.

Anwar, S; Ali, B.; Sajid, I. 2016. Screening of Rhizospheric Actinomycetes for Various In-vitro and In-vivo Plant Growth Promoting (PGP) Traits and for Agroactive Compounds. Front. Microbiol. 7: 1334.

Atkin, C.; Neilands, J.; Phaff, H. 1970. Rhodotorulic Acid from Species of Leucosporidium, Rhodosporidium, Rhodotorula, Sporidiobolus and Sporobolomyces, and a New Alanine-Containing Ferrichrome from Cryptococcus melibiosum. Journal of Bacteriology 103(3): 722-733.

Bhattacharyya, P.N.; Jha, D.K. 2012. Plant growthpromoting rhizobacteria (PGPR): emergence in agriculture. World J. Microbiol. Biotechnol. 28: 13271350.

Calvo, P. 2008. Capacidad PGPR de Bacterias del género Bacillus aisladas de la rizosfera del cultivo de Papa (Solanum tuberosum) en los Andes del Perú. Tesis de grado, Universidad Nacional Agraria de la Molina, Lima. Perú. 152 pp.

Camacho, M.; La Torre, M. 2015. Efecto promotor de bacterias PGPR sobre cultivo de papa bajo diferentes sustratos a nivel de invernadero. The Biologist (Lima) 13(1): 75-89.

Celis, J.; Gallardo, I. 2008. Estandarización de métodos de detección para promotores de crecimiento vegetal (ácido indol acético, giberelinas) en cultivos microbianos. Tesis de grado, Pontificia Universidad Javeriana, Bogotá. Colombia. 159 pp.

Cook, A.; Meyers, P. 2003. Rapid identifications of filamentous actinomycetes to the genus level using genus-specific 16S rRNA gene restriction fragment patterns. International J. of Systematic and Evolutionary Microbiol. 53: 1907-1915.

Crowley, D.A. 2006. Microbial siderophores in the plant rhizosphere. In: Barton, L. L.; Abadia, J. (eds). Iron nutrition in plants and rhizospheric microorganisms. Springer. Netherlands. Pp 169-189.

Doumbou, C.; Hamby, S.M.; Crawford, D.; et al. 2001. Actinomycetes, promising tools to control plant diseases and to promote plant growth. Phytoprotection 82(3): 85-102.

FAO - Organización de las Naciones Unidas para la Agricultura y la Alimentación. 2008. Gestión de las plagas y enfermedades de la papa. Available at: http://www.fao.org/potato-2008/es/lapapa/IYP5es.pdf

Franco, M. 2008. Evaluación de caracteres PGPR en Actinomicetos e interacciones de estas rizobacterias con hongos formadores de micorrizas. Tesis de doctorado, Universidad de Granada, Granada. España. 261 pp.

Franco, M.; Chavarro V. 2016. Actinobacteria as Plant Growth - Promoting Rhizobacteria. In: Open Access books Built by scientists, for scientists, Chapter 10 . Available at: https://www.intechopen.com/books/actinobacteriabasics-and-biotechnologicalapplications/actinobacteria-as-plant-growthpromoting-rhizobacteria

Gunmarsson, N.; Mortensen, U.K.; Sosio, M.; et al. 2004. Identification of Entner-Doudoroff pathway in an antibiotic-producing actinomycetes species. Molec. Microbiol. 52(3): 895-902.

Han, D.; Wang, L.; Luo, Y. 2018. Isolation, identification, and the growth promoting effects of two antagonistic actinomycete strains from the rhizosphere of Mikania micrantha Kunth. Microbiological research 208: 1-11.

Hernández, A. 2002. Obtención de un biopreparado a partir de rizobacterias asociadas al cultivo del maíz (Zea mays L.). Tesis de doctorado. Universidad de La Habana, La Habana. Cuba. 100 pp.

IDEXCAM - Investigación y Desarrollo de Comercio Exterior de la Cámara de Comercio de Lima. 2018. Papa, milenario producto andino. Available at: https://www.camaralima.org.pe/repositorioaps/0/0/ par/estudio4/papamilenarioproductoandino.pdf

Jog, R.; Pandhya, M.; Nareshkumar, G.; et al. 2014. Mechanism of phosphate solubilization and antifungal activity of Streptomyces spp. isolated from wheat roots and rhizosphere and their application in improving plant growth. Microbiology 160: 778-788.

Li, Y.; Guo, Q.; He, F.; et al. 2019. Biocontrol of Root Diseases and Growth Promotion of the Tuberous Plant Aconitum carmichaelii Induced by Actinomycetes Are Related to Shifts in the Rhizosphere Microbiota. Soil Microbiology 19: 134147.

Matsukawa, E.; Nakagawa, Y.; limura, Y.; et al. 2007. Stimulatory effect of indole-3-acetic acid on aerial mycelium formation and antibiotic production in Streptomyces spp. Actinomycetologica 6:1-8.

Olanrewaju, O.S.; Babalola, O.O. 2019. Streptomyces: implications and interactions in plant growth promotion. Applied Microbiology and Biotechnology 103: 1179-1188.

Oswald, A.; Calvo, P. 2009. Using rhizobacteria to improve productivity of potato. In 15th Triennial International Society for Tropical Root Crops (ISTRC), Lima, 2-6 nov, 2009.

Rico, M. 2009. Capacidad promotora de crecimiento vegetal por bacterias del género Azotobacter y Actinomicetos aislados de cultivos de Solanum tuberosum Linnaeus, 1753 (Papa) cultivados en zonas altoandinas del Perú. Tesis de grado, Universidad Nacional Mayor de San Marcos, Lima. Perú.152 pp.

Rodríguez, H.; Fraga, R.; Gonzalez, T.; et al. 2006. Genetics of phosphate solubilization and its potential applications for improving plant growth-promoting bacteria. Plant and Soil 287(1): 15-21.

Salazar, A.; Ordoñez, C. 2013. Aislamiento e identificación de actinomicetos fijadores de nitrógeno en suelo del Jardín Botánico de la Universidad Tecnológica de Pereira. Tesis de grado, Universidad Tecnológica de Pereira, Pereira. Colombia. $115 \mathrm{pp}$.

Sathya, A.; Vijayabharathi, R.; Gopalakrishnan. 2017. Plant growth-promoting actinobacteria: a new strategy for enhancing sustainable production and protection of grain legumes. 3 Biotech 7: 102.

Sreevidya, M.; Gopalakrishnan, S.; Kudapa, H.; et al. 2016. Exploring plant growth-promotion actionmycetes from vermicompost and rhizosphere soil for yield enhancement in chickpea. Brazilian Journal of Microbiology 47(1): 85-95.

Simon, P.; Tessman, I. 1963. Thymidine-requiring mutans of phage T4. Proc. Natl. Acad. Sci. USA. 50: 526-532.

Valdés, M.; Pérez, N.; Estrada, P.; et al. 2005. NonFrankia Actinomycetes Isolated from SurfaceSterilized Roots of Casuarina equisetifolia Fix Nitrogen. Appl. Environm. Microb. 71(1): 445-446.

Vásquez, P.; Holguin, C.; Puente, M. 2000. Phosphatesolubilizing microorganisms associated with 
rhizosphere of mongroves in a semiarid coastal lagoon. Biol. Fertl. Soils 30: 460-468.

Wahyudi, A.; Priyanto, J.; Afrista, R.; et al. 2019. Plant growth promoting activity of actinomycetes isolated from Soybean Rhizosphere. Online Journal of Biological Sciences 19(1): 1-8.
Wang, W.; Qiu, Z.; Tan, H.; et al. 2014. Siderophore production by actinobacteria. Biometals 27: 623-631

Zahir, A.Z.; Arshad, M.; Frankenberg, W.T. 2004. Plant Growth Promoting Rhizobacteria: Applications and Perspectives in Agricultura. Advances in Agronomy 81: 97-108. 